\title{
SCALE TO MEASURE STRESSFUL CHARACTERISTICS IN EDUCATIONAL ENVIRONMENTS: A CASE OF A MEXICAN UNIVERSITY
}

\author{
Beltran-Sanchez JA ${ }^{1 *}$ and Dominguez $\mathrm{A}^{1,2}$ \\ ${ }^{1}$ Tecnologico de Monterrey, Escuela de Medicina y Ciencias de la Salud, Mexico \\ ${ }^{2}$ Universidad Andres Bello, Chile
}

\begin{abstract}
When students enter the university, they undertake a series of activities that can potentially stress them and cause their training experience to be not ideal for their learning. It is the responsibility of higher education institutions to provide an optimal environment to acquire knowledge and skills; therefore, they must have instruments that measure the degrees of stress generated. This study's objective was to determine a scale's psychometric properties that measure stressful characteristics in educational environments, namely Semestre $i$. A cross-sectional study with a survey design was carried out. Two hundred sixty-two university students participated, 122 of whom were men with a mean age of 22.6 $(S D=1.4)$, and 140 were women with a mean age of $22.1(S D=1.2)$. A scale comprised of saturation dimensions (11 items) and unpredictability dimensions (7 items) was obtained. An Exploratory Factor Analysis was performed with the Maximum Likelihood extraction method and oblimin rotation to determine the construct validity. It was possible to explain $52.3 \%$ of the variance $\left(X^{2}=2566.64, d f=153, \mathrm{p}=.001 ; K M O=.92\right)$ in two dimensions, namely, high demand environment and unpredictable environment. Reliability was calculated through internal consistency using the Cronbach coefficient, obtaining an alpha value of .92 . A parsimonious scale was obtained with the necessary evidence to conclude that valid and reliable data can be obtained, allowing the students' stressful educational contexts to be identified and modified or intervened to generate a healthy learning environment.
\end{abstract}

Keywords: Stress, Student, Scale, Semestre i, Educational Innovation, Higher Education

\section{Introduction}

Nowadays, administrators and institutions in education have paid much attention to wellness and diminishing mental health problems. The promotion of mental health has become a priority in developing countries, mainly due to the increasing numbers of students with mental health problems. Stress is one of the principal sufferings of students, which has aroused the interest of the scientific community for several years to conduct investigations into the connection of stress with school (Babakova, 2019; Verger et al., 2009), leaving behind the belief that the student population is one of least affected by this condition (Reddy et al., 2018).

The concept of stress has a great history and tradition in the study of health. According to Lazarus and Folkman (1984), this concept has been used for several centuries. However, it not until Hans Selye's studies and reports in the 1950s that it became systematically conceived as an object of study. 
Currently, stress has been defined according to three well-known concepts in the literature: (1) stress as a stimulus refers to external stimuli that are capable of destabilizing a person physiologically and psychologically, (2) stress as a response refers to people's physiological, emotional, or behavioral responses to various stressors, and (3) stress as an event-reaction relationship focuses on the particular relationship between the person and his environment and how it can be perceived as a threat that overcomes his resources and well-being (Escobar Espejo et al., 2011).

Stress is a cause of alarm and risk factor in the educational field (Suldo et al., 2018). It is understood as the interaction of academic environmental stressors, the cognitive appraisal of students, and their reactions to exceeding psychological resources (Ngozi-Aihie \& Ijeoma-Ohanaka, 2019; Reddy et al., 2018), which are subjective responses (Branson et al., 2019). Examples include defensive behaviors, neglect of relationships, chronic fatigue, sleep deprivation, poor performance in academic achievement, depression, difficulty concentrating, and nervousness (Escobar Espejo et al., 2011; Kumaran \& Javid, 2016; Suldo et al., 2015).

From a psychosocial perspective, the surroundings or environment play a primary role in the absence or presence of stress. It is defined as the set of situations that normatively or contingently structures players' interactions in a delimited organizational space (Barraza et al., 2009). In an educational context, the environment includes students' relationships with peers and teachers and their experience with the teaching and learning practices.

One of the foremost universities in Mexico, Tecnologico de Monterrey (2019), characterized by being open to change and disruption in education, recognizes the need to have leaders who tackle and solve social problems creatively. It sees education's and university's role as a challenge provider to inspire constructive, positive, and open-minded thinking; it encourages to continuously innovate, reinvent, restructure and have a reflective and dynamic perspective, always attentive to society's varying needs and the events that affect it. With this core orientation of the university, it is not a surprise that the Tec21 Educational Model (Tec21) aims to "prepare students to become leaders who are capable of facing the challenges of the 21st century." The previous model was already developing highly technical, competent professionals, emphasizing ethics and citizenship, leadership, and entrepreneurship capabilities. Tec21 builds upon the prior model by adding more competencies that leaders for the 21st century will need (International Finance Corporation, 2019).

Tec21 is a complex educational model that delivers disciplinary and cross-cutting competencies through four main pillars: (1) learning based on challenges, (2) flexibility, (3) memorable university experiences, and (4) inspiring professors. It also establishes learning communities' enablers characterized by educational innovation, educational spaces, and connection with the environment. Moreover, Tec21 aims to offer...

..."educational experiences to shape individuals into agents of change willing to work for the benefit of all - individuals who take responsibility for their own lives and are aware that their actions can transform others - capable, talented, upright, committed, involved visionaries with a global perspective and entrepreneurial spirit, not only at the university but in all spheres of their lives" (Tecnologico de Monterrey, 2018, p. 1).

Before Tec21, from 2016 to 2021, the university carried out various initiatives incorporating the model's ideas, one of those was Semestre i. It is an academic program based on competencies that 
seeks to strengthen and develop students' skills through experiential learning activities. Students take on one or more challenges from real contexts or situations currently encountered by businesses, organizations, or industries (Tecnologico de Monterrey, 2017). Founded on challenge-based learning, Semestre i allows students to work collaboratively with an external client on a problematic real-world situation. Academic programs offer the experience as optional. The students are fully immersed for one academic semester. All the semester courses are concatenated, and students get credit for that set of curricular subjects. The designers select and organize the contents and methods to align with the challenge and the curriculum for accreditation purposes. The course subjects do not have a marked sequence and are considered learning modules; they are offered to solve the challenge. Figure 1 illustrates the scheme used by Regis-Hernandez et al. (2020) to implement a Semestre i in Engineering.

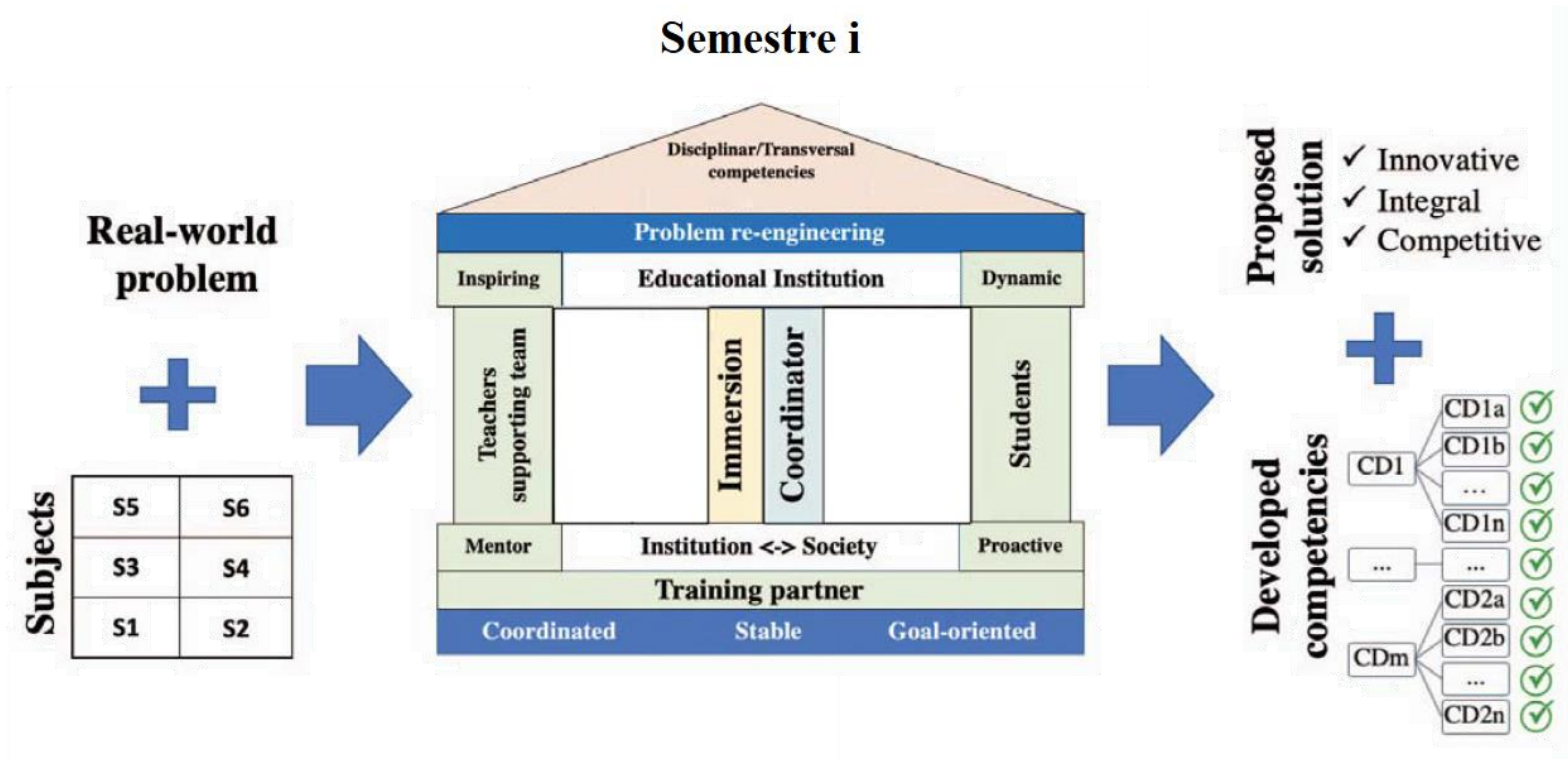

Figure 1. Schematic of the Semestre $i$ academic experience applied in the Engineering program at Tecnologico de Monterrey. Image adapted from Regis-Hernandez et al. (2020).

Another salient feature of this innovation is the roles taken on by the participants in the training process. The students and the teaching team are joined by an outside development partner, the company, industry, or organization that presents real-world challenges. Thus, the methodology gives rise to a triad of training. The teaching team coordinates everything; they are responsible for maintaining successful connections among the three roles.

Like any innovation or disruptive process, Semestre i brings a series of implications for the student body. Initially, we must consider the change in the traditional learning process, which is suddenly changed. Now the rigid-sequential structure of the contents is different and is taught in modules of variable duration and adjusted to the challenge. Likewise, the resolution of a real challenge with real consequences for real people represents motivation and responsibility. Naturally, the student will carry out a cognitive appraisal that assigns relevance to the possible outcomes that, presumably, can become a source of stress (Barraza et al., 2009).

A couple of studies have been carried out indicating that the Semestre i methodology promotes student commitment to their learning. They enjoy the process. It gives meaning to what is taught; the students become conscious of their learning by applying theory to the practical exercises. Students 
undergo an entire semester in professional practice by solving a real problematic situation by applying knowledge, abilities, and competencies. They develop transversal skills such as innovation and entrepreneurship (Lozano-Rodríguez et al., 2019; Roman-Flores et al., 2020). However, there are also findings that greater expenditures of energy and effort (Palma-Mendoza et al., 2019) and confusion if the objective of Semestre $i$ is not clear (Mora-Salinas et al., 2019) lead the students to experience increasing stress through time (Lozano et al., 2019). Finally, there are numerous studies about academic stress's effect on the well-being and performance of students. However, not many instruments measure students' academic stressors (Babakova, 2019; Verger et al., 2009). Those works that consider academic stress do not emphasize studying the environment (Barraza-Macías, 2019). Thus, this study aims to determine the metric properties of an instrument that measures stress factors in educational settings to have a tool that timely detects environments jeopardizing the students' wellbeing during their training process and provides information for redesigning the surroundings.

\section{Method}

This report focuses on the students' perspective of Semestre i. The study design is cross-sectional, descriptive, and quantitative, supported by a survey. It is a typical design in social and behavioral studies in which instruments measure numerical variables (Creswell, 2012; Ruel et al., 2018). It follows the description of the sample, instrument design, and procedures implemented. It is crucial to clarify that this study is part of a larger project that took place in the academic community of Tecnologico de Monterrey, an HEI with 26 campuses throughout Mexico. The study used a mixed methodology with a parallel convergent design to identify faculty and students' burnout in Semestre i.

\section{Sample}

Through a non-probabilistic convenience sampling, 262 students in a private university in Mexico participated, of which 122 were men with an average age of 22.6 ( $S D=1.4$ years), and 140 were women with a mean age of 22.1 ( $S D=1.2$ years). Table 1 displays the educational programs from which the most significant number of students came from the 38 professional programs.

Table 1: The academic programs of participating students

\begin{tabular}{lll}
\hline Academic program & $n$ & $\%$ \\
\hline B.S. in Industrial Engineering with minor in Systems Engineering & 37 & 14.12 \\
\hline B.A. in International Business & 21 & 8.02 \\
\hline B.S. in Digital Music Production & 17 & 6.49 \\
\hline B.S. in Biotechnology Engineering & 17 & 6.49 \\
\hline B.A. in International Logistics & 16 & 6.11 \\
\hline B.A. in Business Administration & 15 & 5.73 \\
\hline B.A. in Financial Management & 15 & 5.73 \\
\hline B.A. in Business Creation and Development & 11 & 4.20 \\
\hline B. A. in Architecture & 10 & 3.82 \\
\hline B.A. in Marketing and Communication & 10 & 3.82 \\
\hline B.A. in International Relations & 10 & 3.82 \\
\hline Others & 83 & 31.68 \\
\hline
\end{tabular}




\section{Instruments}

The authors applied a modified version of the Barraza-Macías (2019) proposed Inventory of Stressful Institutional Characteristics. This survey uses a four-point Likert scale (totally agree, agree, disagree, and totally disagree) and has 25 items in six measured dimensions: (1) highly demanding environments, (2) environments with novel demands, (3) environments highly unpredictable in their demands, (4) environments poorly controllable in their demands, (5) environments with high-duration demands, and (6) environments with high-intensity demands.

A content analysis of the inventory was performed by four researchers with experience in conducting studies in psychology and education. All the survey items were relevant to Semestre i; two of them ask to evaluate two behaviors in the same statement, so they were separated resulting in two additional items.

\section{Procedure}

This study followed the steps of a process of research as stated by Creswell (2012). Figure 2 summarized the research procedure.

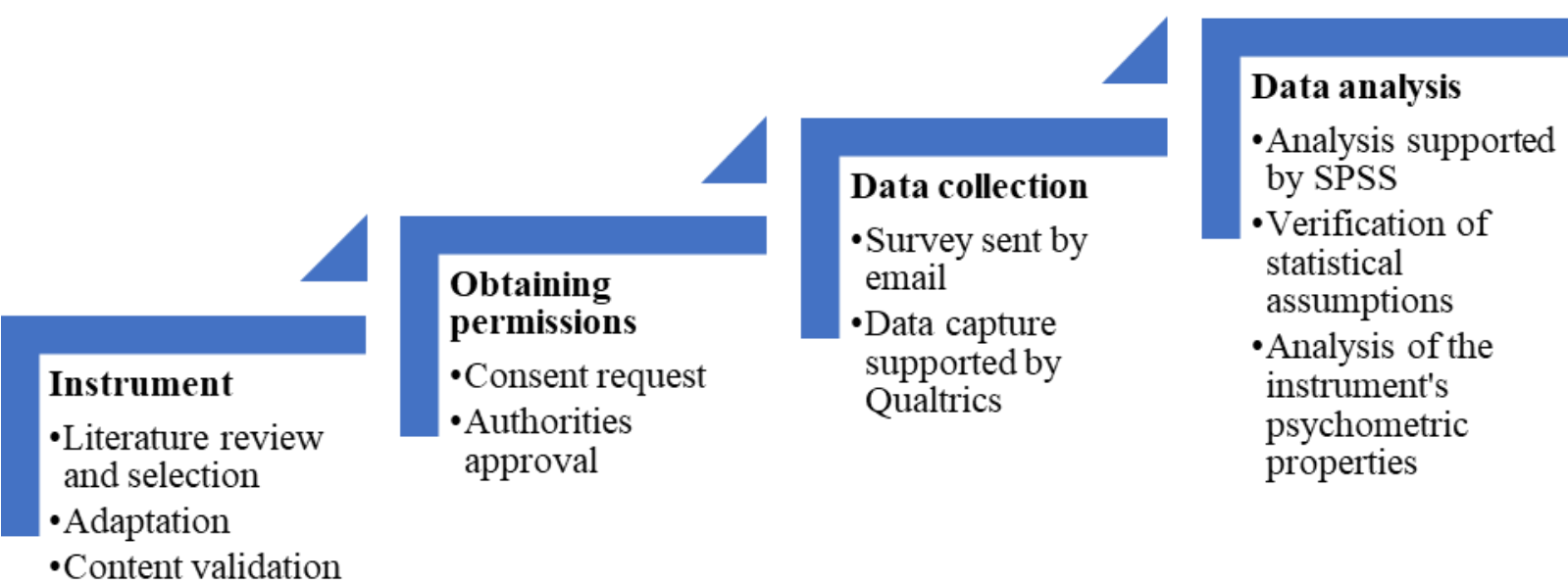

Figure 2. Conducted procedure from selecting the instrument to the analysis.

The steps (Figure 2) to select and validate the scale measuring stressful characteristics in educational settings are described as follows:

1. Search and selection of the measuring instrument. Literature review to identify validated stress scales in English or Spanish.

2. Adaptation of the selected survey. Once we decided the instrument, the adaptation process took place. Specifically, the modification consisted of including the environment, Semestre i.

3. Content validation through the judging process. We asked four accredited academics to conduct research studies in psychology and education to validate the instrument.

4. Consent request to the university authorities to apply the survey. Researchers collected consent requirements and approvals from the corresponding authorities. 
5. Application of the instrument. Students received an invitation to respond to the survey. They were informed that the data collected was confidential and that participation was voluntary.

6. Data capture supported by Qualtrics. Researchers assigned ID numbers to each participant and created a key file to conceal their identities. From then on, researchers only worked with the ID numbers to keep data collected anonymously.

7. Data analysis. The statistical assumptions were large sample, normality, linearity, and homogeneous sample and results were calculated using SPSS version 26.

8. Report of the instrument's psychometric properties results.

Points 1 and 2 were based on the search for scales that report metric properties. The expert validation was done with the support of four researchers.

\section{Results}

The evidence of instrument validity and reliability are presented in this section. The theoretical sixdimensional model was evaluated and resulted in a reduced, two-dimensional, empirical model that meets the criteria established for this procedure, thus obtaining a good fit.

\section{Construct validity}

This instrument's metric properties were obtained using the extraction method of the maximum likelihood method and with oblique rotation, getting a good fit of the proposed model with the empirical model. This result can be verified by the significance scores of Bartlett's test of sphericity and Kaiser-Meyer-Olkin (KMO) values. The criteria for inclusion of items for the construct validity were:

- Data normality calculated through kurtosis and skewness scores using the \pm 1.5 criteria (George \& Mallery, 2019).

- Values equal to or greater than .30 in the item communalities (De Vellis, 2012).

- Factor loads greater than .35 , a criterion proposed for samples greater than 250 participants (Hair et al., 1999).

- Values in the KMO test above .90 (George \& Mallery, 2019).

- Explained variance greater than $50 \%$, an adequate criterion for Social Sciences studies (Cea, 2004; Hair et al., 1999; Merenda, 1997).

To determine the psychometric properties of the proposed scale, we performed an Exploratory Factor Analysis (EFA). The EFA is a multivariate analysis test that analyzes the relationships among variables (interdependence). Its purpose is to group variables according to shared variability. The result is an outcome of a factorial model. This test is done with the Principle of Parsimony, seeking to have the simplest possible model, i.e., with the fewest variables (Cea, 2004; Field, 2009). The results obtained are favorable because the Bartlett sphericity test is fulfilled $\left(X^{2}=2566.64 ., d f=153, p=\right.$ .001 ), and the $K M O$ value is equal to .92 , so the proposed model has a good fit (Cea, 2004). Likewise, Table 2 shows that the scale has 18 items falling into two dimensions: High Demand Environment (11 items) and Unpredictable Environment (7 items), which explains $52.3 \%$ of the variance. 
Table 2. Factor loads and commonalities of the items to measure the characteristics of stressful environments.

\begin{tabular}{|c|c|c|c|}
\hline \multirow{2}{*}{ Items } & \multicolumn{2}{|c|}{ Factors } & \multirow{2}{*}{$h^{2}$} \\
\hline & $\mathrm{F} 1$ & $\mathrm{~F} 2$ & \\
\hline There was so much homework assigned to me in Semestre i that I had less time for myself. & .84 & & .66 \\
\hline $\begin{array}{l}\text { The activities assigned by most of our Semestre i teachers were so complicated that we } \\
\text { needed to invest a lot of time to carry them out. }\end{array}$ & .82 & & .58 \\
\hline $\begin{array}{l}\text { During Semestre i, there were so many activities that I had to carry out that I needed to stay } \\
\text { up at night to complete the assignments. }\end{array}$ & .82 & & .56 \\
\hline $\begin{array}{l}\text { Throughout the entire Semestre i, most of the teachers gave us so much work to do that } \\
\text { there was no time to rest. }\end{array}$ & .79 & & .67 \\
\hline $\begin{array}{l}\text { My Semestre i was characterized by the teachers giving assignments that took a long time to } \\
\text { complete. }\end{array}$ & .76 & & .58 \\
\hline Throughout Semestre i, I felt overwhelmed by too many assignments. & .74 & & .61 \\
\hline $\begin{array}{l}\text { Most of the Semestre i teachers gave us a lot of work, thinking that we only had to do the } \\
\text { activities related to their module. }\end{array}$ & .63 & & .52 \\
\hline $\begin{array}{l}\text { The type of evaluation used by Semestre i teachers was so complicated that we were forced } \\
\text { to dedicate more time to study. }\end{array}$ & .59 & & .48 \\
\hline Most of the Semestre i teachers, at the end of one activity, immediately gave us another. & .58 & & .37 \\
\hline $\begin{array}{l}\text { The activities that had to be carried out in Semestre i were so complicated that "I saw no } \\
\text { end in sight." }\end{array}$ & .58 & & .51 \\
\hline $\begin{array}{l}\text { Most of the Semestre i teachers requested that we complete very complex activities or tasks } \\
\text { quickly. }\end{array}$ & .53 & & .39 \\
\hline $\begin{array}{l}\text { Most of the Semestre i teachers never made it clear to us the evaluation process; until the } \\
\text { last moment, we knew how they were going to do it. }\end{array}$ & & .79 & .57 \\
\hline Most of my Semestre i teachers improvised the activities assigned to us. & & .76 & .54 \\
\hline $\begin{array}{l}\text { In Semestre i, each teacher was so different that it was impossible to know how they would } \\
\text { evaluate us. }\end{array}$ & & .73 & .55 \\
\hline Most of my Semestre i teachers did not explain what we would do. & & .68 & .48 \\
\hline Semestre i teachers assigned activities without making the instructions clear. & & .67 & .53 \\
\hline In Semestre i, the teachers decided everything; the students had neither voice nor vote. & & .62 & .44 \\
\hline Most of the Semestre i teachers decided on the form of evaluation without considering us. & & .59 & .39 \\
\hline
\end{tabular}

\section{Reliability}

This psychometric property was determined by calculating internal consistency using Cronbach's alpha coefficient. The High Demand Environment dimension achieved a score of .91, and the Unpredictable Environment dimension attained a value of .87. Both values are considered very good by De Vellis (2012).

\section{Conclusions}

The study of stress, like any related to the mental health of the student community, is of paramount importance. Higher Education Institutions are responsible for ensuring the control of this problem to promote a pleasant experience and guarantee students' well-being throughout their academic journey. To accomplish this, the institution must provide the instruments to measure the presence of stress and mental disequilibrium. Along these lines, this analysis allows identifying areas of opportunity in 
which institutions can make modifications, whether they are for programmatic factors (e.g., physical environment) or changes in curricular and teaching methodologies. The institutions are the principal promoters of the courses and the teaching methods.

There are different survey instruments and scales to measure stress in students. Some of them focus on burnout (Boada-Grau et al., 2015); others have perfectible metric properties (Barraza et al., 2009; Liu, 2015); some others do not satisfy the Principle of Parsimony (Alania-Contreras et al., 2020; Jayanthi et al., 2015). We only found one of them that analyzes academic environments (CanquiFlores et al., 2019). On the contrary, the scale presented in this study consists of two dimensions with the necessary metric properties to obtain valid and reliable data. Its application is efficient given its parsimonious structure. Its writing style and simple structure are easily replicable in other educational environments and research settings.

The recommendation is to carry out studies in similar populations, applying a Confirmatory Factor Analysis and completing the criterion validity analysis, whether concurrent or divergent. Another suggestion is to carry out invariance exercises that allow suitable instruments for men and women. This recommendation fundament on multiple reports in which female university students suffer from higher stress levels (Escobar Espejo et al., 2011; Verger et al., 2009). Concerning limitations, the study assumed the complexity of the phenomena representing stress and other factors beyond the surrounding environment. To better understand, it is desirable to incorporate family, economic, social, and cultural factors and consider the positive aspects of stressful stimuli (Suldo et al., 2015). It is necessary to continue studying stress to deepen the understanding and favor a better educational ecosystem for all.

\section{Acknowledgments}

The authors acknowledge the financial and technical support of Coordination of Institutional Research in Educational Innovation and Writing Lab, Institute for the Future of Education, Tecnologico de Monterrey, Mexico, in the production of this work.

Also, we want to acknowledge the operations team of Semestre $i$ for facilitating the implementation of this study and all the student participants.

Finally, we offer a special mention to Alejandra Valencia, Adrián Valle, Amanda Ramos, and Omar Nava for their comments and observation about the instrument.

\section{References}

Alania-Contreras, R. D., Llancari-Morales, R. A., Rafaele de La Cruz, M., \& Ortega-Révolo, D. I. D. (2020). Adaptación del cuestionario de estrés académico SISCO SV al contexto de la crisis por COVID-19. Socialium, 4(2), 111-130. https://doi.org/10.31876/sl.v4i2.79

Babakova, L. (2019). Development of the academic stressors scale for Bulgarian university students. Eurasian Journal of Educational Research, 81, 115-128. https://doi.org/10.14689/ejer.2019.81.7

Barraza-Macías, A. (2019). Validación psicométrica de la versión breve del Inventario de Características Institucionales $\quad$ Estresoras. Psicogente, 23(43), 1-20. https://doi.org/10.17081/psico.23.43.3276 
Barraza, A., Ortega, F., \& Martínez, L. (2009). Instituciones generadoras de estrés. un estudio exploratorio en la universidad pedagógica de durango. X Congreso Nacional de Investigación Educativa, $1-12$. http://www.comie.org.mx/congreso/memoriaelectronica/v10/pdf/area_tematica_14/ponencias/0623F.pdf

Boada-Grau, J., Merino-Tejedor, E., Sánchez-García, J., Prizmic-Kuzmica, A., \& Vigil-Colet, A. (2015). Adaptation and psychometric properties of the SBI-U scale for Academic Burnout in

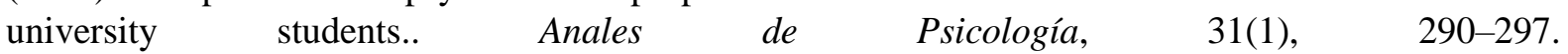
https://doi.org/10.6018/analesps.31.1.168581

Branson, V., Dry, M. J., Palmer, E., \& Turnbull, D. (2019). The Adolescent Distress-Eustress Scale: Development and Validation. SAGE Open, 9(3), 215824401986580. https://doi.org/10.1177/2158244019865802

Canqui-Flores, B., Mendoza-Mollocondo, C., Torres, F.., Fuentes-López, J., Gómez-Campos, R., Viveros-Flores. A., Rivera-Portugal, Margot, \& Cossío-Bolaños, M. (2019). Validez, confiabilidad y baremación para medir la auto-percepción del estrés académico de estudiantes universitarios. Gaceta Médica de Bilbao, 116(4), 158-165. http://www.gacetamedicabilbao.eus/index.php/gacetamedicabilbao/article/view/717/725

Cea, M. de los Á. (2004). Análisis multivariable. Teoría y práctica en la investigación social ( $\left.2^{\text {nd }} \mathrm{ed}.\right)$. Síntesis.

Creswell, J. W. (2012). Educational Research: Planning, conducting and qualitative research (4 ${ }^{\text {th }}$ ed.). Pearson.

De Vellis, R. (2012). Development Theory and Applications ( $3^{\text {rd }}$ ed.). SAGE Publications.

Escobar Espejo, M., Blanca, M. J., Fernández-Baena, F. J., \& Trianes Torres, M. V. (2011). Adaptación española de la escala de manifestaciones de estrés del student stress inventory (SSI-SM). Psicothema, 23(3), 475-485.

Field, A. (2009). Discovering Statistics Using SPSS. SAGE Publications.

George, D., \& Mallery, P. (2019). IBM SPSS Statistics 25 Step by Step: a simple guide and reference (14th ed.). Routledge.

Hair, J., Anderson, R., Tatham, R., \& Black, W. (1999). Análisis Multivariante (5 ${ }^{\text {th }}$ ed.). Prentice Hall. International Finance Corporation. (2019). Breaking Paradigms to develop Leaders for the 21st century. Tec de Monterrey: How a top university in Mexico radically overhauled its Educational Model. Case study. https://www.ifc.org/wps/wcm/connect/industry_ext_content/ifc_external_corporate_site/education/pu blications/tec+de+monterrey

Jayanthi, P., Thirunavukarasu, M., \& Rajkumar, R. (2015). Academic stress and depression among adolescents: A cross-sectional study. Indian Pediatrics, 52(3), 217-219. https://doi.org/10.1007/s13312-015-0609-y

Kumaran, S. J., \& Javid, A. (2016). Emotional Intelligence, Test Anxiety and Academic Stress of Students. Education in Modern Society, 16, 159-167.

Lazarus, R., \& Folkman, S. (1984). Stress, Appraisal, and Coping. Springer Publishing Company, Inc.

Liu, Y. (2015). The longitudinal relationship between Chinese high school students' academic stress and academic motivation. Learning and Individual Differences, 38, 123-126. https://doi.org/10.1016/j.lindif.2015.02.002

Lozano-Rodríguez, A., García-Vázquez, F. I., Zubieta-Ramírez, C., \& Lopez-Cruz, C. S. (2019). Competencies associated with Semestre i and its relationship to academic performance: A case study. Higher Education, Skills and Work-Based Learning, 10(2), 387-399. https://doi.org/10.1108/HESWBL-07-2019-0092 
Lozano, A., Alvarado, M., \& Llaven, M. (2019). Development of competencies in the context of the Semester i: A case study. Education in the Knowledge Society, 20, 121-1214. https://doi.org/10.14201/eks2019_20_a12

Merenda, P. F. (1997). A guide to the proper use of factor analysis in the conduct and reporting of research: Pitfalls to avoid. Measurement and Evaluation in Counseling and Development, 30(3), 156164. https://doi.org/10.1080/07481756.1997.12068936

Mora-Salinas, R., Rosales, C. , Castillo, D. H., Gijón, C. R., \& Rodriguez-Paz, M. X. (2019). The isemester experience: Undergraduate challenge-based learning within the automotive industry. IEEE Global Engineering Education Conference, EDUCON, April-2019, 505-509. https://doi.org/10.1109/EDUCON.2019.8725200

Ngozi-Aihie, O., \& Ijeoma-Ohanaka, B. (2019). Perceived Academic Stress among Undergraduate Students in a Nigerian University. Journal of Educational and Social Research, 9(2), 56-66. https://doi.org/10.2478/jesr-2019-0013

Palma-Mendoza, J. A., Rivera, T. C., Solares, I. A. A., Campos, S. V., \& Velazquez, E. P. (2019). Development of competencies in industrial engineering students immersed in SMEs through challenge-based learning. TALE 2019 - 2019 IEEE International Conference on Engineering, Technology and Education. https://doi.org/10.1109/TALE48000.2019.9225932

Reddy, K., Rajan-Menon, K., \& Thattil, A. (2018). Academic Stress and its Sources Among University Students. Biomedical and Pharmacology Journal, 11(1), 531-537. https://doi.org/10.13005/bpj/1404

Regis-Hernandez, F., Martinez-Medina, G., Borjas-Vazquez, H. C., \& Olais-Govea, J. M. (2020). Semestre $i$ as an active methodology to modify the teaching-learning process in engineering. IEEE Global Engineering Education Conference, EDUCON, 2020-April, 652-666. https://doi.org/10.1109/EDUCON45650.2020.9125372

Roman-Flores, A., Cuan-Urquizo, E., Ramirez-Mendoza, R., Vargas-Martinez, A., Lozoya-Santos, J., Urbina-Coronado, P. D., \& Morales-Menendez, R. (2020). Design of interactive learning cyberphysical tools for mechanical design engineering courses. IEEE Global Engineering Education Conference, EDUCON, 2020-April, 1044-1048. https://doi.org/10.1109/EDUCON45650.2020.9125377

Ruel, E., Wagner, W. E., \& Gillespie, B. J. (2018). The Practice of Survey Research: Theory and Applications. https://doi.org/10.4135/9781483391700

Suldo, S. M., Dedrick, R. F., Shaunessy-Dedrick, E., Roth, R. A., \& Ferron, J. (2015). Development and Initial Validation of the Student Rating of Environmental Stressors Scale. Journal of Psychoeducational Assessment, 33(4), 339-356. https://doi.org/10.1177/0734282914552164

Suldo, S. M., Shaunessy-Dedrick, E., Ferron, J., \& Dedrick, R. F. (2018). Predictors of Success Among High School Students in Advanced Placement and International Baccalaureate Programs. Gifted Child Quarterly, 62(4), 350-373. https://doi.org/10.1177/0016986218758443

Tecnologico de Monterrey. (2017). Semestre $i$. https://semestrei.tec.mx/semestre-i

Tecnologico de Monterrey. (2018). About us: Formation that transforms lives. https://tec.mx/en/about-us/formation-transforms-lives

Tecnologico de Monterrey. (2019). Rumbo al 2030. https://tec.mx/es/plan-estrategico-2030

Verger, P., Combes, J.-B., Kovess-Masfety, V., Choquet, M., Guagliardo, V., Rouillon, F., \& PerettiWattel, P. (2009). Psychological distress in first-year university students: socioeconomic and academic stressors, mastery and social support in young men and women. Social Psychiatry and Psychiatric Epidemiology, 44(8), 643-650. https://doi.org/10.1007/s00127-008-0486-y 